\title{
Kuasi-mugimendutze prozesu baterantz? Bizkaian gobernatzen duten "herri-plataforma independenteak» (1991-2017)
}

\author{
Towards a quasi-mobilization process? \\ The popular platforms that govern in Biscay (1991-2017)
}

Miriam Ureta García • miriam.ureta@ehu.eus

Igor Ahedo Gurrutxaga • igor.ahedo@ehu.eus

UNIVERSIDAD DEL PAÍS VASCO/EUSKAL HERRIKO UNIBERTSITATEA

(UPV/EHU)

Recibido: 22/08/2017

Aceptado: 01/12/2017

\section{Laburpena}

1991z geroztik fenomeno hau detektatu da Bizkaian: «herri-plataforma independenteak» sortu dira eta haien ordezkagarritasunak gora egin du. Horregatik, gure lehenengo helburua da ikerketaren analisi-unitatea definitzea, eta, horretarako, Gemma Ubasartek Katalunian egindako azterketak birplanteatu ditugu azpikategoria propio bat sortuz: «herri-plataforma independenteak», alderdi konbentzionaletatik, "marka zurietatik», eszisiotik eta koalizioetatik bereizten den azpikategoria. Bigarren helburua fenomeno hau karakterizatzea da, bere mugaketa (i) denboraren, (ii) lurraldearen eta (iii) laginen ikuspuntutik justifikatuta; eta baita fenomenoari zentzua ematea ere, haren sorkuntzaren testuingurua analizatuta. Hirugarren helburua da ekarpen teoriko bat egin eta era praktikoan gauzatzea, gizarte-mugimenduen erakundetze-prozesuen argudioak alderantzikatuta. Horrela, kuasi-mugimendutze prozesu bat proposatzen du ikerketa honek, non hasierako konfigurazio alderdikari batetik gizarte-mugimenduen antzeko eredu baterantz egon daitekeen ibilbidea aztertzen den. Lan honen helburuak bete ahal izateko, zortzi elkarrizketa sakon egin zaizkie herri-plataforma independenteetako zinegotziei, eta lortutako emaitzek ustezko kuasi-mugimendutze prozesua argitzen lagundu digute, batez ere analisi-unitatea gobernuan dagoen lehenengo urteei begira.

Hitz-gakoak: «herri-plataforma independenteak», «kuasi-mugimendutze» prozesua.

\section{Abstract}

From 1991 on, a phenomenon has been identified in Biscay: the emergence of «community independent platforms» and its growth in terms of representation. Therefore, the first goal is to define them after reconsidering the work of Gemma Ubasart in Catalonia, from which it has been possible the construction of a subcategory that distinguises «independent community platforms» from political parties, their "white brands", spin-offs and coalitions. The second objective is to characterise the mentioned phenomenon, motivating its (i) temporary, (ii) territorial and (iii) sample delimitation, while the context of the phenomenon is explained. The third goal develops a theoretical contribution: reversing the discussions about the institutionalization of social movements in order to suggest the quasi-movementation approach, which analizes the potential evolution from an initial partisan configuration towards a model similar to social movements. So as to achieve the objectives of the study, eight in-depth interviews to mayors have been carried out, and the results show the possibility of the quasi-movementation process.

Key words: «local community platforms», quasi-movementation process. 


\section{1. «HERRI-PLATAFORMA INDEPENDENTEEN» DEFINIZIOA}

Gemma Ubasartek (2012a: 145; 2012b: 32) sailkapen bat garatu zuen, non alderdi politiko tradizionalak ez ziren tokiko sigla guztiak izendatzeko "hautagaitza bitxia» kontzeptua erabili zuen. Kategoria horretan azpikategoria hauek bereizi zituen Ubasartek: «hautagaitza independenteak», «marka zuriak» eta "herri-hautagaitza alternatiboak» (azken horretan jarri zuen arreta bereziki). Irizpide hori erreferentziazkoa da Euskal Autonomia Erkidegoaren kasuan, nahiz eta Kataluniatik datozen kontzeptuak berraztertu egin diren, euskal errealitatera moldatzeko ${ }^{1}$ (Ureta 2017b). Zentzu horretan, eta aurretiko azterketei jarraituz, kategoriak eta definizioak biltzen dituen taula egin dugu; hala, EAEren kasuan, sigla handietatik kanpo dauden hautagaitza guztiak eta, gainera, tokiko mailan baino aurkezten ez direnak, «tokiko hautesle-elkarteak» izango dira, eta kategoria orokor horren baitan azpi-kategoriak hauek egongo dira:

Lehenik, «marka zuriak». Hautagaitza horiek (i) alderdi politiko konbentzionalenak dira, baina hauteskundetara sigla ofizialekin aurkeztu beharrean, beste izen bat hartzen dute arrazoi estrategikoengatik, idiosinkratikoengatik edo legezkoengatik (ii); izan ere, Euskal Autonomia Erkidegoan ezker abertzalearen «marka zuriak» sortu dira ilegalizazioaren ondorioak (edo ilegalizazioa bera) saihestu eta udalerri batzuetan hauteskundeetara aurkeztu ahal izateko, bereziki 2003., 2007. eta 2011. urteetan. Era berean, azpikategoria horretan sartzen dira (iii) herri mailako alderdi-egitura zehatz bat(zu)en gabezia(k) betetzeko aurkezten diren formazioak, eta fenomeno hori bi garaitan detektatu da bereziki: lehenik 1979an, ezinezkoa zelako alderdi politikoen egitura antolatzea demokraziaren lehenengo urteetan udal guzti mailan; eta bigarrenik 2015an, Podemos alderdi politikoak beste sigla batzuekin hartu zuenean parte hauteskundetan, erakundeak ez zuelako denborarik izan herri mailako egitura antolatzeko. (iv) «Marka zuriak» dira, era berean, koalizioak osatuz aurkezten diren alderdi politikoak, baina beste izen bat hartzen dutenak beste alderdi batzuekin batera aurkezteko. Azkenik, (v) eszisioak ere «marka zuriak» dira lan honetan, eta baita (vi) transfugek osatutako hautagaitzak ere.

Bigarren azpikategoria —ikerketa honetan interes handiena eragiten duena- «herri-plataforma independenteek» osatzen dute. Hautagaitza horien «ezaugarri nagusia da tokiko errealitateak direla» (Ubasart, 2012a: 144), eta hala aldarrikatzen dute. Gainera, azterketa horren egileek adierazten dute herri-ekimenok autonomoak direla alderdi politiko handie-

\footnotetext{
${ }^{1}$ Ubasarten ekarpenekin alderatuta, Euskadin proposatutako sailkapenaren aldaketa nagusiak hauek dira: lehenik, Ubasartek «hautagaitza bitxiak» terminoa zerabilen kategoria orokor gisa, bainaEAEn "hauteskundeelkartea» kontzeptua erabiltzea erabaki da, balorazio-karga txikiagoa duelako. Bigarrenik, Ubasartek «eszisioen ondoriozko hautagaitzak» ezartzen zituen «hautagaitza independenteak» azpikategoriaren barruan; hala ere, ikerketa honek «eszisioen ondoriozko hautagaitzak» azpikategoria bereizi eta "marka zuriak» azpikategoriarekin elkartzeko beharra ikusten du. Hirugarrenik, lan honetan sakondu egin da bai «herri-plataforma independenteen» definizioan, haren izaera autonomoa nabarmenduz, bai «marka zurien» definizioan. Laugarrenik, Ubasartek «herri-hautagaitza alternatiboak» azpikategoria sartu zuen, baina EAEnez da begiesten azpikategoria hori. Bosgarrenik, EAEn «Herri Hautagaitzak» azpikategoria sartu da eta, azkenik eta seigarrenik, Ubasartek politizazio mailaren arabera sailkatu zituenazpikategoriak, baina EAEnez zaio jarraitu irizpide horri.
} 
kiko. Hau da, «herri-plataforma independenteak» ez daude —eta ez dira inoiz egon— alderdi tradizionalekin lortuta, ez organikoki, ez antolakuntza mailan, ez ekonomikoki ezta estrategikoki ere. Zentzu horretan, «herri-plataforma independenteak» ez dira "marka zuriak»; izan ere, ez dira sortzen ezker abertzalea hauteskundeetara aurkeztu ahal izateko, ez dira egituratzen alderdi tradizionalek tokiko mailan dituzten gabezia estrukturalak asetzeko, ez dituzte koalizioak osatzen alderdi handiekin, eta ez dira transfuga taldeak. Bestalde, ez dira «Herri-hautagaitzak» eta, beraz, "herri-plataforma independenteak» «marka zurietatik» eta «Herri Hautagaitzetatik» bereiz daitezkeen errealitatea dira.

Azkenik, hirugarren azpimota «Herri-hautagaitzak» dira. Hautagaitza horiek herri oso txikietan (250 biztanlera arte) agertzen dira eta hauteskunde-zerrenda irekiak dituzte, 1985eko Hauteskunde Araubide Orokorraren Lege Organikoan (HAOLO) ezarri eta 2011n birformulatu zen bezala. «Herri-hautagaitzak» HAOLOan ezarritako legezko berariazkotasunetik sortzen dira, nahiz eta berariazkotasun horrek ez duen galarazten alderdi politiko konbentzionalek ere udalerriotako hauteskundeetan parte hartzea. Taula honetan azpikategorien definizioak jaso dira:

1. taula. Hauteskunde-elkarteen azpikategoriak Euskal Autonomia Erkidegoan

\begin{tabular}{|l|l|}
\hline «Hauteskunde-elkarteen» azpimotak & \multicolumn{1}{|c|}{ Definizioa } \\
\hline «Marka zuriak» & $\begin{array}{l}\text { Hauteskundeetara beste sigla batzuekin aurkezten diren } \\
\text { alderdi politiko tradizionalak, beren baitan alderdi } \\
\text { tradizionalak dituzten koalizioak, eszisioak eta transfuga } \\
\text { taldeak. }\end{array}$ \\
\hline «Herri-plataforma independenteak» & Alderdi politikoekiko autonomoak diren herri-hautagaitzak. \\
\hline «Herri-hautagaitzak» & $\begin{array}{l}\text { Udalerri oso txikietako hautagaitzak, HAOLOaren arabera. } \\
\text { Zerrenda irekiak dituzte. }\end{array}$ \\
\hline
\end{tabular}

Iturria: Egileek egina (Ureta, 2017a; Ureta, 2017b).

\section{FENOMENOAREN EZAUGARRIAK}

Lehenengo eta behin, Euskal Autonomia Erkidegoko «tokiko hauteskunde-elkarteen» aulki kopuruaren bilakaera aurkeztuko dugu taula baten bitartez, eta kategoria orokor hori azpikategoriatan banatuko dugu — «marka zuriak», «herri-plataforma independenteak» eta «Herri-hautagaitzak»² - ikerketaren denbora-mugak justifikatze aldera, beste ikerketa batzuetan egin izan den bezala (Ureta, 2017b):

\footnotetext{
2 Ikerketa honetako kategoria orokorra azpikategoriatan banatu da, lehen atalean aurkeztutako definizioak jarraituz eta ondoriozko pauso metodologiko hauen arabera: (i) hauteskundeetako portaeraren behaketa herriz herri (1991tik 2015era), (ii) ezaguera-iturri arruntekiko kontrastea, eta (iii) zalantzak daudenean, Udalei zuzenean egindako kontsultak.
} 
2. taula. EAEko «tokiko hauteskunde-elkarteen» bilakaera, azpikategorien arabera (19792015)

\begin{tabular}{|c|c|c|c|c|c|c|c|c|c|c|}
\hline Hauteskunde-urtea & 1979 & 1983 & 1987 & 1991 & 1995 & 1999 & 2003 & 2007 & 2011 & 2015 \\
\hline \multicolumn{11}{|c|}{ «Tokiko hauteskunde-elkarteen» bilakaera } \\
\hline Aulkiak & 594 & 278 & 220 & 175 & 232 & 223 & 329 & 340 & 329 & 402 \\
\hline \multicolumn{11}{|c|}{ «Marka zurien» bilakaera } \\
\hline Aulkiak & 578 & 237 & 105 & 91 & 110 & 80 & 190 & 159 & 130 & 189 \\
\hline \multicolumn{11}{|c|}{ «Herri-plataforma independenteen» bilakaera } \\
\hline Aulkiak & 16 & 41 & 38 & 26 & 36 & 53 & 58 & 80 & 112 & 126 \\
\hline \multicolumn{11}{|c|}{ «Herri Hautagaitzen» bilakaera } \\
\hline Aulkiak & $-^{3}$ & $-^{4}$ & 77 & 58 & 86 & 90 & 81 & 101 & 87 & 87 \\
\hline
\end{tabular}

Iturria: Egileek egina (Ureta, 2017b).

Datuok bi ziklo erakusten dituzte, «tokiko hauteskunde-elkarteak» kategoria orokorraren eta "herri-plataforma independenteak» azpikategoriaren ordezkagarritasun mailei dagokienez. Lehenengo zikloak 1979tik 1991ra bitarte irauten du eta, bigarren zikloak, 1991tik 2015era.

Lehenengo zikloari dagokionez (1979-1991), «tokiko hauteskunde-elkarteen» ordezkagarritasun handia azpimarra daiteke alde batetik, politizazio maila handia zelako 1979an, eta ezinezkoa zelako denbora gutxian alderdi politiko handien egitura antolatzea EAEko herri guztietan. Beste alde batetik, «herri-plataforma independenteen» hazkundea garai horretako politizazio maila altuaren ondorio izan daiteke. Beste ikerketa batzuen arabera, herri-elkarteen hazkundea erlazionatuta dago demokrazia ezarri aurreko urteetako «herri-elkarteen legalizazio masiboarekin»; gainera, herri-elkarteetako buruen «kooptazioa» gertatu zen behin «lehenengo udaletxe ordezkagarrietan» elkarte horiek instituzionalizatu zirenean, eta horrek ere zerikusia du aipaturiko hazkundearekin (Villasante, 1992a: 36).

Hala ere, «tokiko hauteskunde-elkarteen» eta "herri-plataforma independenteen» boom horren ostean, demokraziaren lehenengo urteetan, nola kategoria orokorrak hala azpikategoria guztiek behera egiten zuten eta aulki gutxiago lortu zituzten euskal udaletan 1991ra arte. Beherakada horren arrazoiak beste lan batzuetan aztertu izan dira, eta agerian gelditu da elkarteetako parte-hartzearen gainbehera gertatu zela «desmobilizazioagatik» (Villasante, 1992a: 37) eta «aldarrikapen-izaera» galtzeagatik (Villasante, 1992a: 37-40).

Aldiz, 1991tik aurrera, nola «tokiko hauteskunde-elkarteen» hala "herri-plataforma independenteen» bigarren hazkunde-zikloa hasi zen, bereziki 1991tik 2015era bitarte, garaiko

\footnotetext{
3 «Herri Hautagaitzak» azpikategoria 1985ean legalizatu zen formalki, HAOLOaatera zenean.

4 «Herri Hautagaitzak» azpikategoria 1985ean legalizatu zen formalki, HAOLOaatera zenean.
} 
testuingurua definitzen duten faktore estruktural hauengatik (Ureta, 2017b): (i) gero eta zilegitasun txikiagoa duten instituzioak eta demokrazia ordezkatzailearen sistema (Subirats, 2001), "gizarte-mobilizazioaren garrantzi gero eta handiagoa» (Subirats, 2016: 109) eta aktore goiztiar berriei «herri-hautagaitza berriak» (Subirats, 2016: 15) sortzeko ireki zaien Aukera Politikoaren Lehioa (Tarrow, 1992: 118), alternatiba izateko eta demokraziaren kalitatea hobetzen saiatzeko (Montero et al., 2006; Navarro et al., 2009). Dinamika horren protagonistak (ii) tokiko gobernuak dira, "bultzada handia jaso eta indartu egin direlako» (Borja, 1990: 674; Brugué eta Gomá, 1998: 18); izan ere, "partekatutako lurraldearen ohikotasunean soilik aurkitzen dute erantzuteko gaitasuna artikulatzeko» (Subirats, 2016: 10), «arazo zehatzak behetik konpontzeko» (Villasante, 1992b: 28) eta "sozializazio politikoa sustatzeko oinarria» (Borja, 1990: 656). Logika horiek (iii) globalizazioaren biziagotze-prozesu baten barruan kokatzen dira, eta, ondorioz, derrigorrezkoa da «tokiko arazoak testuinguru globalean kokatzea, eta (...) tokiko mailatik maila globalarekin hitz egitea» (Subirats et al., 2002: 17), «behetik abiatuta, munduko orden berria» eraikitzeko (Subirats, 2016: 10).

Bigarrenik, ikerketaren lurralde-mugaketa justifikatu behar da (Ureta, 2017b), eta, horretarako, taula bat aurkeztuko dugu, non analisi-unitateak — «herri-plataforma independenteek»- bigarren hazkunde-zikloan (1991-2015) izandako bilakaera agertzen den. Bilakaera hori Lurralde Historikoen arabera banatuta dago, aztertzen ari garen fenomenoak Bizkaian eragin berezia duela ikusteko; izan ere, Bizkaia da «herri-plataforma independente» gehien sortu eta gora egin duten lurraldea:

3. taula. «Herri-plataforma independenteen» bilakaera, Lurralde Historikoen arabera (1991-2015)

\begin{tabular}{|l|c|c|c|c|c|c|c|}
\hline Hauteskunde-urtea & $\mathbf{1 9 9 1}$ & $\mathbf{1 9 9 5}$ & $\mathbf{1 9 9 9}$ & $\mathbf{2 0 0 3}$ & $\mathbf{2 0 0 7}$ & $\mathbf{2 0 1 1}$ & $\mathbf{2 0 1 5}$ \\
\hline Bizkaia & 24 & 32 & 42 & 37 & 43 & 76 & 84 \\
\hline Gipuzkoa & 2 & 3 & 3 & 2 & 10 & 12 & 8 \\
\hline Araba & - & 1 & 8 & 19 & 27 & 24 & 34 \\
\hline
\end{tabular}

Iturria: Egileek egina (Ureta, 2017b).

«Herri-plataforma independenteen» progresio handiena Bizkaian gertatu izatea eragin duten faktore azpimarragarrienetako bat hauxe da: analisi-unitatea alternatiba sortzaile bat izan daitekeela Bizkaian, alderdi politiko nagusia den EAJren hegemoniari aurre egiteko —Gipuzkoan eta Araban indar politikoak zatituagoak daude-.

Hirugarrenik, fenomenoaren karakterizazioa findu dugu, Bizkaian gobernatzen duten eta ikerketan parte hartu duten ${ }^{5}$ «herri-plataforma independenteak» analisi-unitatetzat har-

\footnotetext{
${ }^{5}$ Murueta eta Zaratamo herriek ez dute ikerketa honetan parte hartu.
} 
tuta (Ureta, 2017b). Erabaki hori muga metodologikoengatik hartu da, eta baita Bizkaian gobernatzen duten "herri-plataforma independenteak» direlako jarduteko eta erabakitzeko ahalmen handiena dutenak. Beraz, hurrengo taulan (i) Bizkaiko (iii) «herri-plataforma independente» (ii) gobernatzaileen bilakaera ikusten da: Abadiñoko Independenteak Abadiñon, ADIE Orozkon, Armendu Ibarrangelun, Karrantza Zabala Karrantzan, La Voz del Pueblo Etxebarrin eta Zalla Bai Zallan.

4. taula. Bizkaiko «herri-plataforma independente» gobernatzaileen bilakaera (1991-2015)

\begin{tabular}{|l|c|c|c|c|c|c|c|}
\hline \multicolumn{8}{|c|}{ Bizkaian gobernatzen duten «herri-plataforma independenteen» bilakaera } \\
\hline Hauteskunde-urtea & $\mathbf{1 9 9 1}$ & $\mathbf{1 9 9 5}$ & $\mathbf{1 9 9 9}$ & $\mathbf{2 0 0 3}$ & $\mathbf{2 0 0 7}$ & $\mathbf{2 0 1 1}$ & $\mathbf{2 0 1 5}$ \\
\hline Aulkiak & 6 & 9 & 13 & 13 & 22 & 38 & 43 \\
\hline
\end{tabular}

Iturria: Egileek egina (Ureta, 2017a; Ureta, 2017b).

\section{PROPOSAMEN TEORIKOA: KUASI-MUGIMENDUTZE PROZESUA}

Behin lehenengo bi helburuak landu ondoren (gure azterketa-xedearen mugaketa teoriko eta aplikatua), azterketa honen hirugarren xedea da Bizkaian gobernatzen duten "herriplataforma independenteen» (1991-2017) 6 eskutik kuasi-mugimendutze prozesu bat gertatzen ari ote den jakitea. Hau da, ea lanaren analisi-unitatea hasiera batean alderdi politiko bati legokiokeen konfiguraziotik gizarte-mugimenduen antz handiagoa duen konfigurazio batera igaro ote den ikustea.

Ikerketa-galdera horrek indar handiagoa du kontuan hartzen badugu Bizkaian gobernatzen duten «herri-plataforma independente» guztiak ez direla sortu gizarte-mugimenduek aldez aurretik planifikatutako estrategia batetik abiatuta eta gerora instituzionalizatu eta alderdi politikoaren ezaugarriak hartuta ${ }^{7}$. Aitzitik, egiaztatu da Bizkaian gobernatzen duten «herri-plataforma independente» gehienak proiektu politiko nahiko «espontaneoetatik» sortu direla, hauteskundeetan parte hartzeko urgentziak bultzatuta, kuasi-mugimendutze hipotesiak funtziona dezakeen lekuetan; esate baterako, Etxebarrin, Ibarrangelun, Orozkon eta Zallan.

Bien bitartean, Abadiño eta Karrantza ez dira kontuan hartu azterketa honetan, kuasimugimendutze hipotesia ez baita hasieratik betetzen haietan. Abadiñon eta Karrantzan instituzionalizazio-prozesuak gertatu dira (i), eta, esate baterako, Abadiñoko Trafikoaren

\footnotetext{
${ }^{6}$ Ikus erlazionatutako ikerketa, «herri-plataforma independenteak» osatzen dituzten aktore kolektiboen tipologiari buruzkoa (Ureta, 2017b).

${ }^{7}$ Ikus herri-munizipalismo alternatiboko subjektu politikoen instituzionalizazioari buruzko ikerketa eta Cortinak eta Ubasartek (2010) instituzionalizazio-teorien inguruan egindako berrikusketak.
} 
Kontrako Plataforma zeritzona Abadiñoko Independenteak izeneko «herri-plataforma independente» bihurtu zen, interes-taldearen mugimendu-eredu batetik abiatuta (Rucht, 1999: 266), eta (ii) Karrantza Naturala zeritzon oinarrizko mugimendu ekologista (Rucht, 1999: 266) instituzionalizatu eta Karrantza Zabala bilakatu zen.

Hortaz, gehiago sakondu dugu fenomenoaren karakterizazioan, azterketa honen behin betiko lagina osatzeko; hau da: (ii) Bizkaiko (i) «herri-plataforma independenteak», (iii) dagozkien udalerrietan gobernatzen dutenak eta (iv) kuasi-mugimendutze hipotesia betetzeko aukera dutenak. Hurrengo taulan artikulu honetako ikerketaren behin betiko lagina jaso da:

5. taula. Etxebarri, Ibarrangelu, Orozko eta Zallak osatutako laginaren bilakaera

\begin{tabular}{|l|c|c|c|c|c|c|c|}
\hline \multicolumn{8}{|c|}{ Bizkaian gobernatzen duten «herri-plataforma independenteen» bilakaera } \\
\hline Hauteskunde-urtea & $\mathbf{1 9 9 1}$ & $\mathbf{1 9 9 5}$ & $\mathbf{1 9 9 9}$ & $\mathbf{2 0 0 3}$ & $\mathbf{2 0 0 7}$ & $\mathbf{2 0 1 1}$ & 2015 \\
\hline Aulkiak & 6 & 9 & 9 & 9 & 14 & 27 & 31 \\
\hline
\end{tabular}

Iturria: Egileek egina.

Beraz, lagina osatzen duten plataformak -Etxebarri, Ibarrangelu, Orozko eta Zallakuasi-mugimendutze prozesu baterako hautagaiak dira, ez dira sortu eta gizarte-mugimenduetatik. Lagineko udalerrietako plataformak funtsezko helburu batekin sortu ziren jatorritik: lehenengo eta behin, alderdi politiko baten itxura hartu nahi zuten, eta, ondorioz, elementu formaletan jarri behar izan zuten arreta beren ibilbidearen hasieran, hauteskundeetara aurkeztu ahal izateko (sinadura bilketa, hautagaien zerrendak osatu edo legez baliagarria zen gutxieneko barne-egitura bat antolatu). Gainera, «herri-plataforma independenteetako» militante askorentzat horixe izan da politikan izan duten lehen esperientzia, eta maila publikoan antolatu eta ezagutzen ez zituzten herritarrekin harremanetan jarri behar izan dute lehenengo aldiz. Baina orain, politizazio-prozesuak jarri dituzte martxan herritar horiekin batera, eta lehen pertsonal-pribatutzat hartzen ziren arazoak estruktural eta publikotzat hartzen dira orain, eta, ondorioz, politika publikoetan islatu behar dira.

Horrela bada, «herri-plataforma independenteek» politizazio-prozesuak piztu dituztela esaten da. (i) Sorreran, «herri-plataforma independenteek» minimo formalei eta legezkoei ematen diete lehentasuna hauteskundeetara aurkezteko, eta, horregatik, alderdi politikoen irizpideak bete nahi dituzte. (ii) Gerora, gizarte-mugimenduek berezko dituzten ezaugarriak hartzen dituzte, beren bilakaera-prozesuan. Lan honetan, kuasi-mugimendutzearen hipotesiaren arabera analizatu da bilakaera-prozesu hori eta (iii) hipotesi horrek indarra hartzen du kontuan hartuta analisi-unitateko kideek politizazio-prozesu bat izan dutela. Hipotesi horrek, alderantzizko zentzuan, hurbilketa orijinal eta berritzaile bat proposatzen du gizarte-mugimenduen eta alderdi politikoen arteko harremanera, orain arte 
gizarte-mugimenduen instituzionalizazio prozesuetan jarri izan baita arreta. Hala, ikerketa honen ekarpen nagusia beste ikuspuntu bat da, gutxiago aztertua: gizarte-mugimenduen logikak formazio politikoetan aplikatzea.

Artikulu honen ekarpen teoriko nagusia garatzeko - kuasi-mugimendutze prozesuaren proposamena - Ibarrak eta Letamendiak (1999) egindako taula hartuko da erreferentzia, taula horretan gizarte-mugimenduak eta alderdi politikoak argi eta garbi bereizten baitira kategoria teorikoetan operazionalizatutako zortzi dimentsioren arabera:

6. Taula. Gizarte-mugimenduen eta alderdi politikoen zortzi dimentsioak

\begin{tabular}{|l|l|l|}
\hline \multicolumn{1}{|c|}{ Dimentsioak } & \multicolumn{1}{c|}{ Alderdi politikoak } & \multicolumn{1}{c|}{ Gizarte-mugimenduak } \\
\hline Alderdiekiko erlazioak & \multicolumn{1}{c|}{ - $^{8}$} & Gatazkatsuak \\
\hline Antolakuntza & Hierarkikoa/formalizatua & Horizontala/informala/sarea \\
\hline Interesak & Orokorrak eta zehaztugabeak & Orokorrak eta zehaztugabeak \\
\hline Ordezkaritza-bideak & Konbentzionalak & Ez-konbentzionalak \\
\hline Ekintza kolektiboa & Interes orokorrak gehitu & Interesak eta identitatea \\
\hline Estrategia & Lehiakortasuna & Gatazka \\
\hline Helburuak & Sistemikoak & Potentzialki antisistemikoak \\
\hline
\end{tabular}

Iturria: Ibarra eta Letamendia, 1999.

Aktore politikoak bereizten dituzten zortzi dimentsioen artean, kuasi-mugimendutze prozesua gauzatzeko garrantzitsuak direnak baino ez dira kontuan hartuko, hau da: botere politikoarekiko orientazioa, beste alderdi batzuekiko harremanak, ekintza kolektiboa eta ordezkaritza-bideak. Horiek dira funtsezko bost dimentsioak, besteak kanpoan utzi ondoren arrazoi hauengatik: lehenengo eta behin, baztertu egin dira ordezkatutako taldeak eta interesak, alderdi politikoetarako eta gizarte-mugimenduetarako berdin operazionalizatzen direlako; bigarrenik, estrategiaren dimentsioa ere ez da kontuan hartu, lan honetan aplikatzeko orduan alderdi politikoen arteko erlazioen dimentsioaren antzekoa delako; eta azkenik, helburuen dimentsioa ere ez da kontuan hartu, gizarte-mugimenduen inguruko literatura gehienaren arabera, grosso modo, gizarte-mugimenduen helburuak ez direlako potentzialki antisistemikoak beti ${ }^{9}$. Hortaz, kuasi-mugimendutze prozesuaren proposamen teorikoa atal honetan hautatu diren bost dimentsioen bitartez garatu da.

\footnotetext{
${ }^{8}$ Jatorrizko taulan lauki hau hutsik dago, baina ikerketa honetan kategoria hau berriz formulatu da alderdien arteko harremanak - era orokor batean-lankidetzazkoak eta lehiakortasunezkoak direla interpretatuz.

${ }^{9}$ Adibide argi bat Joshua Cohen-en eta Andrew Arato-ren teoriak dira (2000), «erradikaltasun automugatua» kontzeptuaren ingurukoak. Kontzeptu horrek «erreforma instituzionaleko proiektu automugatzaile eta demokratikoak» ditu aipagai, eta proiektu horiek «diskurtsoaren eta konpromisoaren egiturak zabaltzea eta demokratizatzea dute helburu» (Cohen eta Arato, 2000: 593). Haien teoriek gizarte-mugimenduen proiektu automugatzaileen bidez egindako erreforma instituzionalak azpimarratzen dituzte eta, beraz, helburu antisistemikoak ukatzen dituzte.
} 
Gainera, kuasi-mugimendutze prozesu bat gertatu ahal izateko, aldez aurretiko baldintza hauek bete behar direla defendatzen du artikulu honek: «herri-plataforma independenteak» boterea eraldatu nahi izan behar du, eta, gainera, (ii) barne egitura informala edo horizontala izan behar du hasieratik. "Herri-plataforma independente» batek bi irizpide horiek hasieratik betetzen ez baditu (boterea aldatzeko nahia eta era horizontal batean antolatzea —edo gutxienez ez behintzat modu hierarkikoan, alderdi handiak bezala-) gerora ezin izango ditu - proposamen horren arabera - gizarte-mugimenduen antzeko ezaugarriak lortu. Gainera, sin e qua non diren baldintza horiez gain, behin «herri-plataforma independenteak» ordezkaritza lortu duenean edo boterera heldu denean, kuasimugimendizatu ahal izateko —azterketa honetako hipotesi nagusia baieztatzen bada-, (iii) konbentzionalak ez diren ordezkaritza-bideak erabili behar dira, (iv) ekimenak proiektu-identitateak berreskuratzeko eta indartzeko helburuarekin gauzatu behar dira Castellsen (1997) baldintzen arabera eta (v) oposizioan dauden alderdiekiko harremanek gatazkatsuak izan behar dute.

Kuasi-mugimendutze prozesuari eduki teorikoa emateko, aukeratutako bost dimentsioetako kontzeptu teorikoak operazionalizatu dira. Azaldu den moduan, kuasi-mugimendutze prozesua gauzatu ahal izateko, beharrezkotzat jotzen da gutxienez aldez-aurretiko baldintza hau betetzea: «herri-plataforma independenteek» boterea aldatu eta eraldatu nahi izatea, gizarte-mugimenduek bezala (Blumer, 1946; Wilkinson, 1971; McCarthy y Zald, 1977; Haberle, 1979; Touraine, 1981; Tilly, 1984; Killian eta Turner, 1987; Melucci, 1989; Ibarra, 2005; Diani, 2015). Hori da, beharbada, gizarte-mugimenduen ezaugarri nagusia: "gizartea aldatzeko prozesuan parte hartzeko borondate irmoa» (Casquete, 1998: 21).

Kuasi-mugimendutze prozesua gauzatu ahal izateko bigarren baldintza «herri-plataforma independenteen» antolakuntzarekin lotuta dago; izan ere, antolakuntza-printzipio informal (Killian eta Turner, 1987) eta horizontal (Melucci, 1996) batean oinarrituta funtzionatu behar dute, gizarte-mugimenduek bezala. Horrela, «sare trinkoak osatu behar dituzte» (Della Porta eta Diani, 2011: 43) eta barne-egiturak «ad hoc eta etena izan behar du, testuinguruarekiko sentsibilitatearekin (...) Ohikoa da (...) desberdintzearen antolakuntza-printzipioari ez jarraitzea» (Offe, 1988: 182). Alderdi politikoetan, aldiz, egitura hierarkikoa eta formalizatua da.

Hirugarrenik — kuasi-mugimendutze prozesua sortzen hasteko beharrezkoak diren lehenengo bi baldintzak bete ostean-, beste ezaugarri bat bete behar da: «herri-plataforma independenteek» oposizioko alderdi politikoekin duten harreman mota. Gizarte-mugimenduen kasuan, alderdiekiko harremanak liskartsuak dira: «argi eta garbi identifikatutako aurkariekin harreman gatazkatsuak dituzte» (Della Porta eta Diani, 2011: 43), "objektu bera kontrolatu nahi duten oposizioko eragileen arteko aurkaritza» sortzen da (Touraine, 1981: 80), eta "ondasun eta balore berberak eskatzen dituen aurkariarekin oposizioan» (Melucci, 1989: 29) geratzen dira. Aldiz, alderdi politikoek itunaketa lankidetza-harremanak egiten dituzte haien artean, nahiz eta aldi berean lehiakortasun-sareak osatzen dituzten botoak lortzeko (Vázquez eta Vázquez, 2011: 183-185). 
Halaber, laugarren ezaugarri bat ere aintzat hartu behar da: «herri-plataforma independenteen» ekintza kolektiboaren ordezkaritza-bideek konbentzionalak ez diren dimentsioetan oinarrituta egon behar dute, «ezohiko jokabide-eredu politikoak hartuta» (Della Porta eta Diani, 2011: 51), gizarte-mugimenduek bezala. Horregatik, artikulu honetan honako hauek hartzen dira ekintza ez-konbentzionaltzat: "gizarte-mugimenduek sortu ohi dituzten ekintza urratzaileak, kaleko politika egiten jarraitzea helburu dutenak» (Della Porta eta Diani, 2011: 52); hau da, ekintza kolektibo berritzaileak, demokrazia ordezkatzaileak berezko duen hauteskunde-ordezkaritza urratu eta haratago joaten direnak, alderdi politikoek batez ere hauteskunde-ordezkaritzarekin zerikusia duten irizpideetan oinarritutako mekanismoak erabiltzen dituztelako.

Ekintza ez-konbentzionalak, gainera, kuasi-mugimendutze prozesua ixteko proposamen teorikoan kontuan hartu beharreko bosgarren dimentsioan oinarrituta edo hark indartuta egon daitezke. Hauxe da dimentsio hori: indentitatearen protagonismoa ekintza kolektiboan, gizarte-mugimenduetan gertatzen den bezala. Kuasi-mugimendutze prozesua gauzatu ahal izateko, «herri-plataforma independenteen» ekintzek identitateen eraikuntzan eta sendotzean oinarrituta egon behar dute, eta ezaugarri hori oso garatuta dago gizarte-mugimenduetan (alderdi politikoetan baino askoz gehiago). Identitate kolektiboa da: «Ekintza kolektiboari eskainitako aukera —eta hertsadura - eremuaren definizio partekatua» (Taylor eta Whittier, 1992: 105; Melucci, 1999: 38). «Partekatua izateak esan nahi du gizarte-harremanak aktibatzeko prozesu jarraituen bidez eraikia eta negoziatua izan dela» (Taylor eta Whittier, 1992: 105) eta «kideen interesetan, esperientzietan eta elkartasunean duela jatorria».

Beraz, partaidetzatik haratago doan kidetasun-sentimendua da (Diani, 1998; Casquete, 1998), eta elkartasun-sentimenduak sortzen ditu (Diani, 2015). Beraz, identitatea gizartemugimenduari zentzua ematen dion oinarrizko ardatza da, zeren eta kideek «gizartemugimenduak eraikitako ikuspuntuaren arabera (...) ikusten eta bizi izaten dute errealitatea" (Ibarra, 2005: 85). Identitate hori pragmatikoa, erresistentziazkoa edo proaktiboa izan daiteke, eta ikerketa honi gehien interesatzen zaiona proaktibitatearekin lotuta dagoena da. Proiektu-identitate batek subjektu berriak, "gizartea eraldatzeko agenteak» (Castells, 1997: 90) sorrarazten ditu; eta agente horiek «identitate berri bat eraikitzen dute, gizartean duten kokapena birdefinitzeko eta gizarte-egituren eraldaketa lortzeko» (Castells, 1997: 30).

Azaldu den moduan, kuasi-mugimendutze prozesua gizarte-mugimenduei buruzko literaturatik abiatuta garatzen diren instituzionalizazio-teorien (Gamson, 1990: 91-109; Meyer eta Tarrow, 1998: 20-24; Kriesi, 1999: 247; Ibarra, 2005: 113-115; Tilly, 2010: 299-300; Della Porta eta Diani, 2011: 187) argudioen alderantzikatze teoriko bat da. Horregatik, kuasi-mugimendutze prozesua alderdi politikoen zutabetik gizarte-mugimenduek bereizgarri duten zutaberantz egon daitekeen bilakaera da; eta harreman hori — azpimarratu den bezalaez denez aztertu Akademiaren barruan, artikulu honek hutsune hori bete nahi du. 


\section{HIPOTESIA}

Adierazitakoan oinarrituta, (i) azterketa-xedea kontzeptualki eta testuinguruan kokatu ondoren eta (ii) lan honen oinarri teorikoak aurkeztu ostean, hipotesia formulatu daiteke:

H1: Etxebarrin, Ibarrangelun, Orozkon eta Zallan gobernatzen duten «herri-plataforma independenteak» (1991-2017) kuasi-mugimendutze prozesua jasaten ari dira edo jasan dute.

\section{PLANTEAMENDU METODOLOGIKOA}

\subsection{Diseinuaren tipologia eta ikuspegi metodologikoa}

Esplorazio-diseinua da, azterketa-xedeari buruzko informazio kualitatiborik ez baitago. Hortaz, era berritzailean lan egin nahi izan da, gaiaren inguruko jakintza lortzeko: azterketa-xedeari gerturatzeko, ondoren lan sakonago bat egitearen bideragarritasuna egiaztatzeko, ikerketa-galdera berriak planteatzeko eta etorkizuneko ikerketetan erabili beharreko metodologia birformulatzeko.

Diseinu metodologikoari dagokionez, kualitatiboa da, Eusko Jaurlaritzako Erregistroaren hauteskunde-datuak kontsultatu ostean eta gizarte-mugimenduei buruzko literatura berrikusi ondoren, zortzi elkarrizketa sakon egin direlako. Bina elkarrizketa "pertsonal, holistiko eta erdi-egituratu» (García et al., 1996; Taylor eta Bogdan, 1998; Olabuénaga, 2009; Juaristi, 2003; Sierra, 2003) egin zaizkie lagineko lau alkateei, hain zuzen, eta laginketa intentzionala eta opinatikoa (Olabuénaga, 2009: 66; Taylor eta Bogdan, 1998: 109) edo estrategikoa (Vallés, 2002: 70) izan da.

\subsection{Informazioa aztertzeko teknika}

Literaturaren analisian jatorri duten kategoria teorikoak (Olabuénaga, 2009: 69) eraiki dira kodifikazio-prozesurako; izan ere, analisi kualitatiboa egiterakoan «kategoriekin kodifikatu nahi izaten da, eta ez zenbakiekin» (Olabuénaga, 2009: 69). Emaitzak analizatzeko orduan, haiek interpretatu egin dira elkarrizketak behin eta berriz entzun eta berrirakurri ondoren (Juaristi, 2003: 154). Dimentsioen operazionalizazio teorikoaren arabera, diskurtsoaren mamia zein den zehaztu da: operazionalizazio teorikotik datorren indar-ideia bat ezarri da, testuinguruan kokatu da ondorengo verbatimekin, eta, azkenik, ideia hori aurrekoarekin lotu da. Beti interpretazio-lan bat da, eta diskurtsoaren zatiak aukeratu, esanahiak bilatu eta ideiak behin eta berriro testuinguruan kokatu behar dira (Juaristi, 2003: 154).

\subsection{Kalitatearen kontrola eta etika}

Elkarrizketen kalitate-kontrola bermatzeko kalitatea bermatzeko testa eta egiaztapen testa erabili dira (Taylor eta Bogdan, 1998; Vallés, 2002; Juaristi, 2003; Olabuénaga, 2009). Bi pro- 
zesu horiek etikarekin lotuta daude, tratamendu etikoa informazioaren kalitatearen eta etorkizunean egin daitezkeen azterketen bideragarritasunaren mende ere badago eta. Elkarrizketatuen anonimotasuna bermatzea garrantzitsua da, arazo etikoak saihesteko eta fenomeno honetan lan egiten jarraitu ahal izateko, konfiantza osoz eta elkar errespetatuz.

\section{EMAITZEN AURKEZPENA}

Atal teorikoan azaldu den moduan, aztertutako «herri-plataforma independenteek» alderdi politikoen antzeko konfigurazioa dute sorreran. Izan ere, (i) premiazko momentu batean sortu ziren hautagaitza bat aurkezteko: «Presioaren ondorioz, egun batean aurkeztea erabaki genuen» (E5) «jaietan, bero-bero, esan genuen: aski da, nazkatuta gaude!» (E3). Horregatik, elkarrizketatuek diote hasiera batean (ii) minimo formal eta legezkoak bete behar izan zituztela hauteskundetara joateko, alderdi politikoek bereizgarri dituzten irizpideei jarraiki: «Aralar alderdi politikoak bere siglak utzi zizkigun aurkeztu ahal izateko... bestela, ezin izango ginen aurkeztu, berandu zen eta hautesle-elkartea antolatzeko; eta Aralarrek bere egitura utzi zigun»(E1). Horregatik, (iii) plataforma horien kideek politizazio-prozesu bat bizi izan dute, aurretik ez zutelako mugimendu edo alderdi politikoetan parte hartu; hortaz, hauxe da aztertutako laginaren ezaugarri nagusietako bat: «herri-plataforma independenteak» eratu zirenean, militante-esperientziarik ez zuten pertsonei esker izan zela (E1, E2, E3, E4).

\subsection{Aurretiko lehen baldintza: Boterea aldatzeko nahia}

Legitimitate-krisia eta herritarren nahigabea da "herri-plataforma independenteen" sorrera eta hazkunde-fenomenoa azaltzen duen faktore nagusia, fenomeno horri esanahia ematen diona, eta horixe da kuasi-mugimendutze prozesua gertatu ahal izateko bete behar den lehen baldintza. Kasu guztietan, elkarrizketatuek nahigabe politikoa lotu dute herriko proiektuen artikulazioarekin eta boterea aldatzeko nahiarekin, Udaletako gobernuetan parte hartuz. Behin elkarrizketatuek esandakoak aztertuta, "aldaketarako bulkada» horren atzean lau arrazoi nagusi daudela ondorioztatzen da: lehenik, «herri-plataforma independenteek» politika egiteko modua eraldatu nahi dute, aurretiko politika egiteko moduak herritarrei gero eta kalte sakonagoa egiten ziela iritzi dutelako (E1, E2, E3, E4, E5, E6, E7, E8); bigarrenik, gainbegiratze-lanak egin nahi dituzte, indar politiko bakar bati erabaki guztiak hartzen ez uzteko, oposizioko alderdien kontrolik gabe (E3, E4, E7, E8); hirugarrenik, auzo marjinal batzuk isolamendutik atera nahi dituzte, baztertuta zeudelako (E4, E5, E7, E8); eta azkenik, udalaz gaindiko erakundeek —Eusko Jaurlaritzak eta Bizkaiko Foru Aldundiak - hartutako erabakiek herriaren interesei kalte egin diezaieten saihestu nahi dute, kontuan hartuta alderdi politiko berberak -EAJk - gobernatzen duela erakunde horietan eta aztertutako «herri-plataforma independenteek» (E1, E2, E3, E4, E5, E6, E7, E8) egoera horri aurre egin nahi diote, eta horrexegatik du Bizkaiak protagonismoa azterketa honetan. 


\subsection{Aurretiko 2. baldintza: Antolakuntza/barne-egitura}

Lortutako emaitzen arabera, «herri-plataforma independenteek» artikulazio informal eta horizontala dute, eta ezaugarri hauek dituzte: (i) oinarrizko egitura, hauteskundetara joan ahal izateko behar diren minimoekin,(ii) rolen edo eginkizunen bereizketa eskasa, (iii) kaleko presentzia eta biltzarirekiak, eta (iv) profil ideologiko anitzeko militanteak. Lehenengo ezaugarriari dagokionez, egitura nahiko sinplea eta pragmatikoa da, aintzat hartuta, gainera, tokiko mailan lan egingo dela herri ertain eta txikietan. Gainera, «herri-plataforma independenteek» badute bigarren ezaugarri komun bat, kalean presentzia izatea, eta, horretarako, estrategia bat behar da herritarrekin konektatuta dauden erabakiak hartzeko, nahiz eta estrategia hori era informal batean planteatuta egon, "gai garrantzitsuei» buruzko hausnarketa bermatzeko (E1, E2, E3, E4, E7, E8). Irekitze horren emaitza gisa hiritarrak integratzeko espazio espezifikoak indartzen dira, herritarrek parte hartzeko egitura gisa eraikitzen diren barne antolakuntzako logiken bidez. «Enpresa bat kontratatu genuen antolatzen laguntzeko (...) gaikako taldeak egin ziren herrian, Udaleko jendea eta guzti, eta bakoitzak gehien interesatzen zitzaion taldean parte hartzen zuen... ingurumenarena da aktiboena... haur-hezkuntzako taldeaeta kultura-gaietakoa ere badaude» (E2). Horrela, «herri-plataforma independenteek» hartutako erabakiak herritarren borondatearekin konektatuta egoteko (E1, E2, E3, E4, E5, E6, E7, E8) saiakera bat dago, eta, ondorioz, kanpokoranzko antolakuntza-egitura bat ezartzen da (E1, E2, E3, E4, E5, E6, E7, E8) demokrazia parte-hartzailearen, hurbiltasun-demokraziaren eta demokrazia deliberatiboaren mekanismoak erabilita, hurrengo azpiatalean, «ordezkaritza-bideak» egituratzeko moduari buruzkoan, ikusiko den moduan.

Azkenik, barneko antolaketari dagokionez partekatzen duten hirugarren ezaugarria da ez dagoela bereizketa sendorik kideen roletan: «Ez zaigu gustatzen zinegotzien eta zinegotzi ez direnen arteko bereizketa egitea... zinegotziek beren postuan egon behar dute formalki, norbaitek joan behar duelako (...) baina zortzigarrena zerrendan badago eta laugarrenak baino aukera eta gogo handiagoa baditu parte hartzeko, bada, laugarrenak baino gehiago parte hartzen du!» (E3). Lana antolatzeko malgutasun hori erlazionatuta dago "herri-plataforma independenteetako» militanteen profil ideologikoaren aniztasunarekin; izan ere, aniztasun horren eraginez ikuspuntu desberdinak sortzen dira: «Aniztasunak aberastu egiten du beti, batzuetan liskarrak sortzen diren arren» (E6). Hala ere, formaltasunik ezak hauskortasuna eragin dezakeela adierazten dute, egitura sendoa, hierarkizatua eta hainbat mailatan banatua ez izateak sostengu animiko, ekonomiko, eta mediatikorik ez izatea esan nahi baitu: «Horrelako talde batean sartzen zarenean, bakarrik zaude arriskuaren aurrean (...) ez daukazu alderdi baten laguntza egiturarik, ezta sostengu animikorik ere... laguntza ekonomikoa edo teknikoa soilik ez da nahikoa» (E7).

\subsection{3. dimentsioa: Alderdiekiko harremanak}

Behin kuasi-mugimendutze prozesu bat gertatzeko beharrezkoak diren bi aurrebaldintzak betetakoan, hirugarren dimentsioa analizatuko dugu: alderdiekiko harremanak. Kasu ge- 
hienetan, "herri-plataforma independenteen» eta alderdi politikoen arteko harremanak nahiko zailak izan dira. Arrazoi nagusia da Bizkaiko udalerrietan Alkatetzak galdu dituzten alderdi politikoek erresistentzia handia jartzen dutela, orain Udal horietan «herri-plataforma independenteak» daudelako gobernatzen (edo baita oposizioko alderdien «hauteskundeetako ehiza-barrutia» nabarmen murriztudelako ere, «etorri berritzat» hartzen diren lehiakideak sortzearekin bat), eta, ondorioz, gatazkak sortu dira (E1, E2, E3, E4, E7, E8). Beste kasu batzuetan, harreman txar horiek ez dute konfrontaziorik eragin, lankidetzarik eza baizik, eta alderdi politikoek ez diete dokumentaziorik edo informaziorik eman nahi izan "herri-plataforma independenteei», edo udal-kudeaketan era arduragabean parte hartu dute (E2). Hala ere, elkarrizketen emaitzek agerian uzten dute legealdiek aurrera egin ahala harremanak ez direla horren gatazkatsuak eta lankidetza areagotu egin dela (E3, E4, E5, E6), bereziki Etxebarrin; eta Orozkoko alderdien arteko harremanak ere leuntzen ari dira apurka-apurka.

\subsection{4. dimentsioa: Ordezkaritza-bideak}

Nahiz eta «herri-plataforma independente» gehienak hauteskundeetan parte hartzeko urgentziak bultzatuta sortu ziren, eta berez alderdi politikoenak eta demokrazia ordezkatzailearenak diren ekintza kolektibo konbentzionalak gauzatu zituzten arren, behin makila lortutakoan ordezkaritza-bide «ez-konbentzionalak» ezarri dituzte geroago. Emaitzek islatzen dutenez, «herri-plataforma independenteak» demokrazia ordezkatzailearen esparrutik haratago joan dira, eta demokrazian sakondu dute gerora, parte-hartzearen, hurbiltasunaren eta deliberazioaren bidez (Ureta, 2017a). Lehenik eta behin, partaidetza-ereduari dagokionez, ikerketa honetan aintzat hartu diren plataformetako batek Parte-hartze bidezko Aurrekontuak egin ditu (E7, E8). Bigarrenik, hurbiltasunezko demokraziari dagokionez, "herri-plataforma independenteek» democratie du proximité delakoaren berezko mekanismoak ezarri dituzte kasu guztietan; hala, (i) herritarren biltzarrak jarri dituzte abian auzo guztietan, politika publikoak batera ezartzeko (E1, E2, E3, E4, 5, E6, E7, E8) eta (ii) gaikako foroak ezarri dituzte herritar guztiek gai zehatzei buruz eztabaidatu ahal izateko (E1, E2, E3, E4, E5, E6, E7, E8). Azkenik, deliberazio-ereduari dagokionez, "gune babestu» gisa funtzionatzen duten Herritar Batzordeak garatu dira (Mansbridge, 1996: 51-60) kasu batean, tradizionalki erabakiak hartzeko prozesuetatik kanpo utzi izan diren sektoreetako kideek haiengan eragina duten gaiak landu ahal izateko, errealitatea eta esku hartzeko estrategia egokienak beraien terminoetan definituta: «Hirugarren Adinekoen gaiarekin hasi gara eta erretirodunen taldeei, anbulatorioko pertsonei... dei egin diegu; gerora, enplegu-gaiei buruzko Herritar Batzordeasortu nahi dugu» (E6).

\subsection{5. dimentsioa: Ekintza kolektiboa}

Aztertutako «herri-plataforma independente» guztiek, behin Alkatetza lortutakoan, haien identitatea lantzeari ekin diote. Elkarrizketatik ondorioztatu denez, identitateak «herriplataforma independenteen» ekintza kolektiboak bideratu ditu hiru motibazio motaren 
bidez: (i) herritarrak auzo zehatz batzuekin identifikatzeari utzi eta herri osoarekin identifikatzen hasteko beharra; (ii) herriei balioa emateko eta herri-identitatea indartzeko asmoa; eta (iii) identitatea eraikitzen duten materialak liburuetan eta aldizkarietan islatuta egoteko nahia. «Herri-plataforma independenteetako» zinegotzien arabera, laneko ardatz nagusietako bat herri-identitatea berreskuratzea da, auzoen arteko tentsio zaharrak gaindituta eta guztiak proiektu komun batean elkartuta: «Lehen ez zegoen herri-identitatearen kontzepturik... herria gauza bat zen, eta auzoak beste bat... horregatik, ez zegoen herrisentimendurik» (E7), auzoen artean euste-hormak bailiran eraiki ziren diferentziengatik, nagusiki historian zehar enkistatutako liskarren ondorioz eta auzoen arteko egitura-berdintasunik ezagatik (E5).

Halaere, identitatea suspertzea eta indartzea lan handia da eta nolabaiteko pedagogia eskatzen du, zaila delako epe motzean auzo zehatz batzuekiko identifikazioa leundu eta tokiko identitate kolektiboa eraikitzea, auzo batzuen arteko harreman gatazkatsuek oraindik ere irauten dutelako (E5, E6). Zentzu horretan, «herri-plataforma independenteetako» alkateek uste dute herri osorako lan egiten bada konexio gehiago eta erlazio hobeak sortzen direla (E5), eta bizikidetzaren kalitatea areagotu egiten dela. «Herri osorako lan egiten dugu eta zerbitzu guztiak ez bikoizten saiatzen gara, jendea elkarrekin nahasteko» (E6) eta haien artean konektatzeko; ikastetxetik bertatik ere egiten den lana da: «Herriko jendea gara eta herriarentzat lan egiteko etorri gara... Eta auzoen eta herriaren nomenklatura nahiko gaiztoa zen une hartan, ez? Behekoak eta goikoak (...) Baina guk hauxe esan dugu: ongi, egia da herrian auzo ugari daudela, baina herria guztiok gara, eta pedagogia hori egiten saiatuko gara... eta pedagogia hori eskolan bertan ere egiten dugu, haurrek unitate didaktiko bat dute eta auzo guztiak elkartuta daudela ulertzeko» (E6). Azken batean, partaidetza-prozesuekin gertatzen den bezala, «nirea» ardatz duen logika batetik (banako bakartua, kasu honetan baita auzoa ere), "gurea» kontuan hartzen duen logika batera (herritarrak, herria) igaro behar da.

Ekintza kolektiboa herri-identitateak gidatzea eragiten duen bigarren motibazioa herriari balioa emateko eta beste udal batzuetatik desberdintzeko eta bereizteko asmoa da (E1, E2, E3, E4, E5, E6, E7, E8). Dena den, zeregin horretan ere egon dira gatazkak, zeren eta identitatea onartzeko borroka irain-sentimenduagatik etorri da, eta, ondorioz, konfrontazioa gertatu izan da batzuetan beste erakunde batzuekin (E1, E2, E5, E6, E7, E8).

Hautagaitzon eskutik ekintza kolektiboa herri-identitate proaktiboak gidatzea eragiten duen hirugarren motibazioak herri-identitatea bultzatzen duten ekimenak ditu emaitza: liburuen eta aldizkarien argitalpena, udalerriaren identitatea indartzea helburu duten museoak zabaltzea edo ekitaldiak eta jaialdiak antolatzea (E1, E2, E3, E4, E5, E6, E7, E8, E9), oraina iraganarekin lotzen duen esparru partekatu bat ezarriz, etorkizunerantz bideratuta eta politika publikoetan oinarrituta dauden ekintzekin batera. 


\section{ONDORIOAK}

Hasiera batean «herri-plataforma independenteak» hautesle-elkarte gisa hauteskundeetan parte hartzeko minimo formalekin konfiguratu ziren arren, badaude gerora gizartemugimenduek berezkoago dituzten ezaugarriak hartzen joan direla eta kuasi-mugimendutze prozesua sortu dela adierazten duten seinaleak. Hala ere, joera bat antzematen da: kuasi-mugimendutze prozesua identifikagarriagoa da lehen gobernu-urteetan, une zehatz batean gertatutako loratze bat bailitzan; izan ere, legealdiek aurrera egin ahala, kuasi-mugimendutze prozesua ikusgai bihurtzen duten dimentsio batzuek indarra gal dezakete. Eta ahultze horrek eraginda, pixkanaka erlazio adeitsuagoak sor daitezke gainerako alderdiekin, tokiko panoraman sendotu ahala. Beraz, etorkizuneko ikerketei begira, beharrezkoa izango da diseinu metodologikoa zabaltzea eta denbora-aldagaia aintzat hartzea.

\section{ERREFERENTZIA BIBLIOGRAFIKOAK}

Blumer, H. (1946). Collective Behaviour. En Lee, A. (eds.), New Outline of thePrinciples of Sociology (pp. 167-220). Nueva York: Barnes and Noble.

Borja, J. (1990). Políticas y gobierno en las grandes ciudades. En Borja, J., Quintana, I. y Castells, M. (eds.), Las grandes ciudades en la década de los noventa (pp. 649-722). Madrid: Editorial Sistema.

Brugué, Q. y Gomá, R. (1998). Gobierno local: de la nacionalización al localismo y de la gerencialización a la repolitización. En Brugué, Q. y Gomá, R. (coords.), Gobiernos locales y políticas públicas (pp.16-23). Barcelona: Ariel.

Casquete, J. (1998). Política, cultura y movimientos sociales. Bilbao: Bakeaz.

Castells, M. (1997). La era de la información, economía, sociedad y cultura. Vol. 2. El poder de la identidad. Madrid: Alianza Editorial.

Cohen, J. y Arato, A. (2000). Sociedad civil y teoría política. Méjico: Fondo de Cultura Económica.

Cortina y Ubasart; M. y G. (2010). Municipalismo alternativo y popular, hacia una definición del concepto». X Congreso de la Federación Española de Sociología, Iruña.

Della Porta, D. y M. Diani (2011). Los movimientos sociales. Una introducción. Madrid: CIS y Editorial Complutense. 
Diani, M. (1992). The Concept of Social Movement. Sociological Review, vol. 40, n. ${ }^{\circ}$ 1, pp. 1-25.

- (1998). Las redes de los movimientos: una perspectiva de análisis. En Ibarra, P. y Tejerina, B. (comp.), Los movimientos sociales. Transformaciones políticas y cambio cultural (pp. 243-270). Madrid: Trotta.

- (2015). Revisando el concepto de movimiento social. Encrucijadas, vol. 9, pp. 1-16. disponible en: http://www.encrucijadas.org/index.php/ojs/article/view/161/145

Gamson, W. (1990). The strategy of social protest. Belmont-California: Wadsworth Press.

García, E., Gil, J. y Gómez, G. (1996). Metodología de la Investigación cualitativa. Málaga: Ediciones Aljibe.

Gobierno Vasco (2017). Resultados Elecciones Municipales y Forales 2015. disponible en http://www.euskadi.net/elecinf/2015/elecciones-municipales-juntas generales/ resultados/municipales/resultados_c.htm

Haberle, R. (1979). Enciclopedia Internacional de las Ciencias Sociales. Madrid: Aguilar.

Ibarra, P. 2005. Manual de la sociedad civil y movimientos sociales. Madrid: Editorial Síntesis.

Ibarra, P. y Letamendia, F. (1999). Los movimientos sociales. En Caminal, M. (eds.), Manual de Ciencia Política (pp. 372-403). Madrid: Tecnós.

Juaristi, P. (2003). Gizarte ikerketarako teknikak. Teoria eta adibideak. Zarautz: Argitalpen Zerbitzua EHU/UPV.

Killian, L. y Turner, R.H. (1987). Collective Behaviour. Englewood Cliffs, NJ: Prentice Hall.

Kriesi, H.P. (1999). La estructura organizacional de los movimientos sociales en su contexto político. En McAdam, D., McArthy, J.D. y Zald, M.N. (eds.), Movimientos sociales, perspectivas comparadas(pp. 221-261). Madrid: Ediciones Istmo.

Mansbridge, J. (1996). Using/FightingPower: the Polity. En Benhabib, S. (eds.), Democracy and difference. Contesting the Boundaries of the Political (pp. 46-66). Princeton: Princeton University Press.

McCarthy, J.D. y Zald, M.N. (1977). Resource Mobilization and Social Movements: A Partial Theory. American Journal of Sociology, vol. 82, n. ${ }^{\circ}$ 6, pp. 1212-41. 
Melucci, A. (1989). Nomads of the Present: Social Movements and Individual Needs in Contemporary Society. London: Hutchinson.

- (1996). Challenging Codes: Collective Action in the Information Age. Cambridge: Cambridge University Press.

—(1999). Acción colectiva, vida cotidiana y democracia. México: El Colegio de México.

Meyer, D.S. y Tarrow, S. (1998). The Social Movement Society. Contentious Politics for a New Century. Maryland: Rowman and Littlefield.

Montero, J.R, Font, J. y Torcal, M. (2006). Ciudadanos, asociaciones y activistas. En Montero, J.R., Font, J. y Torcal, M. (eds.), Ciudadanos, asociaciones y participación en España (pp. 50-70). Madrid: CIS.

Navarro, M., Cuesta, M. y Font, J. (2009). ¿Municipios participativos? Participación política y ciudadanía en las ciudades medias españolas. Opiniones y Actitudes CIS, n. $^{\circ}$ 62, pp. 1-107.

Offe, C. (1988). Partidos políticos y nuevos movimientos sociales. Madrid: Editorial Sistema.

Olabuénaga, J.I. (2009). Metodología de la investigación cualitativa. Bilbao: Universidad de Deusto.

Rucht, D. (1999). El impacto de los contextos nacionales sobre la estructura de los movimientos sociales: un estudio comparado transnacional y entre movimientos. En McAdam, D., McCarthy, J. y Zald, M. (eds.), Movimientos sociales: perspectivas comparadas, (pp. 262-287). Madrid: Istmo.

Sierra, R. (2003). Técnicas de investigación social. Teoría y ejercicios. Madrid: Thompson Editores.

Subirats, J. (2001). Nuevos mecanismos participativos y democracia: promesas y amenazas. En Font, J. (coord.), Ciudadanos y decisiones públicas (pp. 33-42). Barcelona: Ariel.

—(2016). El poder de lo próximo. Las virtudes del municipalismo. Madrid: Catarata.

Subirats, J., Brugué, Q. y Gomá, R. (2002). La agenda y el debate sobre el territorio en la sociedad de las redes. En Subirats, J. (coord.), Redes, territorios y gobierno. Nuevas respuestas locales a los retos de la globalización (pp. 321-351). Barcelona: Diputació de Barcelona.

Tarrow, S. (1994): Power in movement. Social Movements, Collective Action and Politics, Cambridge: Cambridge University Press. 
Taylor, V. y Whittier, N. (1992). Collective Identity in Social Movements Communities: Lesbian Feminist Mobilization. En Morris, A. y Mueller, C. (eds.), Frontiers in Social Movement Theory (pp. 169-194). New Haven: Yale University Press.

Taylor, S. y R. Bodgan (1998). Introducción a los métodos cualitativos. Barcelona: Paidós.

Tilly, C. (1984). Social Movements and National Politics. En Bright, C. y Harding, S. (eds.), StateMaking and Social Movements (pp.297-317). Michigan: University of Michigan Press.

-(2010). Los movimientos sociales, 1768-2008. Desde sus orígenes hasta Facebook. Barcelona: Crítica.

Touraine, A. (1981). The Voice and the Eye: An Analysis of Social Movements. Cambridge: Cambridge University Press.

Ubasart, G. (2012a). Municipalismo alternativo y popular: ¿Hacia una consolidación de las tesis del nuevo localismo y la politización del mundo local? Revista de Estudios Políticos, n. ${ }^{\circ}$ 157, pp. 135-162.

—(2012b). Candidatures alternatives i populars a Catalunya: construint democracia. Barcelona: Icaria.

Ureta, M. (2017a). Profundizar la democracia a través de la inclusión económica y urbana: el caso de las "plataformas vecinales independientes» que gobiernan en Bizkaia (1991-2017). Clivatge, n. ${ }^{\circ}$ 5, pp. 387-414.

— (2017b). La emergencia de las «plataformas vecinales independientes» que gobiernan en Bizkaia: un híbrido entre movimiento social y partido político como alternativa (1991-2017). Encrucijadas, vol. 13, pp. 1-21.

Vallés, M. S. (2002). Entrevistas cualitativas. Madrid: Cuadernos Metodológicos CIS.

Vázquez, D. y Vázquez, J. (2011). La desafección social hacia los partidos políticos. Madrid: J. Vázquez.

Villasante, T. (1992a). El desarrollo local: analizadores y potencialidades desde iniciativas ciudadanas. Política y Sociedad, vol. 10, pp. 17-31.

- (1992b). Experiencias y propuestas sobre la participación ciudadana. Phychosocial Intervention, vol., n. ${ }^{\circ}$ 5, pp. 17-31.

Wilkinson, P. (1971). Social Movements. New York: Praeger. 